\title{
Antioxidant system of ginseng under stress by cadmium
}

\author{
Teresa Cristina Lara Lanza de Sá e Melo Marques ${ }^{1}$, Angela Maria Soares²\% \\ ${ }^{1}$ UFLA - Depto. de Ciência do Solo, C.P. 3037 - 35700-000 - Lavras, MG - Brasil. \\ ${ }^{2}$ UFLA - Depto. de Biologia - Setor Fisiologia Vegetal, C.P. 3037 - 35700-000 - Lavras, MG - Brasil. \\ *Corresponding author < amsoares@dbi.ufla.br> \\ Edited by: Leonardo Oliveira Medici
}

\begin{abstract}
Toxic levels of Cd can cause protein denaturation and oxidative stress, which result in membrane damage, enzimatic activity changes and other metabolic damage. Some plants may show alteration in the activity of their antioxidant enzymes as a heavy metal tolerance mechanism. This study aims at evaluating the role of enzymes of the antioxidant system in adaptive responses of the accumulator $P$. glomerata species to levels of cadmium (Cd). Plants were cultivated in nutrient solutions containing concentrations of Cd in the form of $\mathrm{CdSO}_{4}$ $\left(0,45\right.$ and $\left.90 \mu \mathrm{mol} \mathrm{L}^{-1}\right)$, for $20 \mathrm{~d}$. Cd concentrations and yields of root and shoot dry matter were determined at the end of the experiment. Malondialdehyde (MDA) production and the activities of antioxidant enzymes were determined after days 1, 12 and 20. Higher Cd concentrations in tissues of $P$. glomerata were found to reduce biomass production in both roots and shoots. The lipid peroxidation rates in leaves and roots were smaller at the start of the experiment for all Cd levels. Superoxide dismutase (SOD) activity increased in leaves on day 1 and in roots on day 20 as Cd levels increased. Cd stress induced an increase in the activity of APX in leaves, whereas in roots ascorbate peroxidase (APX) activity was reduced at high concentration of $\mathrm{Cd}$. At the end of the experiment, catalase (CAT) activity in leaves was reduced as $\mathrm{Cd}$ concentration increased. Nevertheless, the glutathione reductase (GR) and guaiacol peroxidase (GPX) activities increased. In roots, GR activity was reduced on days 1 and 20. Keywords: antioxidant enzymes, oxidative stress, tolerance, cadmium toxicity
\end{abstract}

\section{Introduction}

Many heavy metals stimulate the formation of free radicals and reactive oxygen species (ROS), either by direct electron transfer involving metal cations or as a consequence of metal-mediated inhibition of metabolic reactions (Srivastava et al., 2005). Enhanced levels of ROS such as singlet oxygen may activate the pathways that set in train the cell death program (Foyer and Noctor, 2005). Plants that have a well developed defense system against ROS production, limiting their formation, are better equipped to tolerate adverse conditions in their habitat (Alscher et al., 2002). Antioxidants and antioxidant enzymes function to interrupt the cascades of uncontrolled oxidation. These defense systems can remove, neutralize or scavenge oxy-radicals and their intermediates (Foyer and Noctor, 2003).

Superoxide dismutase (SOD) acts as the first line defense against $\mathrm{ROS}$, dismuting $\mathrm{O}_{2}^{-}$to $\mathrm{H}_{2} \mathrm{O}_{2}$. Yet, the product of $\mathrm{SOD}$ activity is still toxic $\left(\mathrm{H}_{2} \mathrm{O}_{2}\right)$ and should be eliminated in subsequent reactions, through the action of $\mathrm{CAT}$, other peroxidases and by the ascorbate-glutathione cycle. The equilibrium of SOD, APX and CAT activities is essential in order to determine the steady-state level of $\mathrm{O}_{2}-$ and $\mathrm{H}_{2} \mathrm{O}_{2}$ (Bowler et al., 1991). For instance, when CAT activity is reduced in plants, other ROS-scavenging enzymes such as APX and GPX are upregulated (Willekens et al., 1997; Vandenabeele et al., 2004).

Pfaffia genus belongs to the family Amaranthaceae, and Pfaffia glomerata is of particular medical interest because its roots are popularly used for anti-tumor, anti-diabetes and aphrodisiac tonic properties (Montanari et al., 1999). Thus, studying its capability to tolerate heavy metals and how much is accumulated in the tissues is interesting since it is widely used as a medicinal plant. Besides that, the need to explore some of the mechanisms used by this species to tolerate metal concentrations has a major scientific interest. This study approached the capacity of $P$. glomerata to tolerate $\mathrm{Cd}$ by variations in the activities of antioxidant enzymes (SOD, CAT, APX, GPX and GR) in leaves and roots with different exposure time to the metal.

\section{Materials and Methods}

Seeds of Pfaffia glomerata (Sprengel) Pedersen were obtained from at the Federal University of Mato Grosso do Sul (UFMS). Seeds of $P$. glomerata were placed directly on polystyrene cell trays containing vermiculite and were left to germinate, after which time they were transferred to a Clark nutrient solution (Clark, 1975). Plants remained in the solution for another three weeks for adaptive purposes and were then transferred to individual vases for treatment induction. $\mathrm{Cd}$ concentrations used in this work were chosen based on Carneiro et al. (2002). Treatments contained three concentrations of $\mathrm{Cd}\left(0,45\right.$ and $\left.90 \mu \mathrm{mol} \mathrm{L}^{-1}\right)$ in the form of $\mathrm{CdSO}_{4}$, and the experiment was conducted for 20 days, with three assessments: 1, 12 and 20 days after treatment induction. Lipid peroxidation and the activities of antioxidant enzymes were determined on each of these dates. After 20 days, biomass production and $\mathrm{Cd}$ concentration in roots and shoots were also assessed.

Biomass analysis at the end of the 20-day-period, the plants were collected, separated into root and shoot fractions, placed in paper bags and taken to an air circulation oven at $70^{\circ} \mathrm{C}$ till constant weight was reached for determination of dry matter. After determining dry matter, samples were ground in a Wiley mill equipped with a $0.38 \mathrm{~mm}$ mesh sieve and subsequent used for the analysis of $\mathrm{Cd}$ content.

For $\mathrm{Cd}$ determination, $\mathrm{HNO}_{3}-\mathrm{HClO}_{4}$ digestion of the dried and ground plant material was performed, and $\mathrm{Cd}$ de- 
termination was carried out on the acid extract by atomic absorption spectrometry (Silva, 1999).

The estimation of lipid peroxidation was based on the production of 2-thiobarbituric acid reactive metabolites, particularly malondialdehyde (MDA), following the methods of Heath and Packer (1968) and Buege and Aust (1978). Samples containing $200 \mathrm{mg}$ of leaf and root tissue were macerated in $5 \mathrm{~mL}$ of $0.1 \%$ TCA (trichloroacetic acid). After complete homogenization, $1.4 \mathrm{~mL}$ of the homogenate was transferred to an eppendorf tube and centrifuged at 10,000 rpm for $5 \mathrm{~min}$ utes. An aliquot of $0.5 \mathrm{~mL}$ of the supernatant was added to $2 \mathrm{~mL} \mathrm{0.5 \%} \mathrm{(v/v)} \mathrm{TBA} \mathrm{(thiobarbituric} \mathrm{acid)} \mathrm{in} \mathrm{20 \%} \mathrm{TCA.} \mathrm{The}$ mixture was heated in a water bath at $95^{\circ} \mathrm{C}$ for 30 minutes and then ice-cooled for 10 minutes. Readings were taken using a spectrophotometer at 535 and $600 \mathrm{~nm}$. The MDA concentration was expressed as $\mathrm{nmol} \mathrm{g}{ }^{-1}$ of fresh tissue.

Extraction of the antioxidant enzymes (SOD, CAT, APX, GPX and GR) was carried from $200 \mathrm{mg}$ of fresh tissue of macerated leaves and roots, with the addition of $800 \mu \mathrm{L} \mathrm{ex}-$ traction buffer containing $100 \mathrm{mmol} \mathrm{L}^{-1}$ potassium phosphate buffer (pH 7.8); $100 \mathrm{mmol} \mathrm{L}^{-1}$ EDTA and $1 \mathrm{mmol} \mathrm{L}^{-}$ ${ }^{1} \mathrm{~L}$-ascorbic acid. The protein content in all samples was determined using the Bradford (1976) method.

Superoxide dismutase assay (SOD; E.C. 1.15.1.1) - The activity of SOD was determined according to its capability to inhibit the photochemical reduction of nitroblue tetrazolium (NBT), as described by Beauchamp and Fridovich (1971). The reaction mixture containing $2 \mathrm{~mL}$ of final volume consisted of $50 \mathrm{mmol} \mathrm{L}^{-1}$ potassium phosphate buffer (pH 7.8), $14 \mathrm{mmol} \mathrm{L}^{-1}$ methionine, $0.1 \mu \mathrm{mol} \mathrm{L}^{-1}$ EDTA, 1 mmol L ${ }^{-1} \mathrm{NBT}, 2 \mu \mathrm{mol} \mathrm{L}{ }^{-1}$ riboflavin and $50 \mu \mathrm{L}$ of protein extract, with riboflavin being added last. Sample test tubes and control test tubes (without samples) were placed under 20W fluorescent light tubes. The reaction was allowed to proceed with the light switched on for $10 \mathrm{~min}$ and then stopped by switching off the light. The reading of solution absorbance was carried out at $560 \mathrm{~nm}$. SOD activity is the measure of NBT reduction in light without protein minus NBT reduction with protein. One unit of activity was defined as the amount of protein required to cause $50 \%$ inhibition of the initial NBT reduction under assay conditions.

Catalase assay (CAT; E.C. 1.11.1.6) - The activity of CAT was determined as described by Kraus et al. (1995), with minor alterations, as described by Azevedo et al. (1998). CAT was determined by spectrophotometry at $28^{\circ} \mathrm{C}$ in a final reaction mixture of $2 \mathrm{~mL}$ containing $100 \mathrm{mmol} \mathrm{L}^{-1}$ potassium phosphate buffer ( $\mathrm{pH}$ 7.0), $12.5 \mathrm{mmol} \mathrm{L}^{-1}$ hydrogen peroxide $\left(\mathrm{H}_{2} \mathrm{O}_{2}\right)$ and water. The reaction was started by adding 30 $\mu \mathrm{L}$ of the extract and the activity determined following the decomposition of $\mathrm{H}_{2} \mathrm{O}_{2}$, for 1.5 minute at 10 -second intervals, monitoring changes in absorbance at $240 \mathrm{~nm}$, with a molar extinction coefficient of $0.0394 \mathrm{mmol} \mathrm{L}^{-1} \mathrm{~cm}^{-1}$. Results were expressed as $\mu \mathrm{mol}$ of $\mathrm{H}_{2} \mathrm{O}_{2}$ consumed per minute per $\mathrm{mg}$ protein.

Ascorbate peroxidase assay (APX; E.C.1.11.1.11) - The activity of APX was determined using the method of Nakano and Asada (1981), estimating the ascorbate oxidation rate (extinction coefficient of $2.8 \mathrm{mmol} \mathrm{L}^{-1} \mathrm{~cm}^{-1}$ ). The reaction mixture containing $100 \mathrm{mmol} \mathrm{L}^{-1}$ potassium phosphate buffer ( $\mathrm{pH} 7.0), 0.1 \mathrm{mmol} \mathrm{L}^{-1}$ hydrogen peroxide $\left(\mathrm{H}_{2} \mathrm{O}_{2}\right), 0.5 \mathrm{mmol} \mathrm{L} \mathrm{L}^{-1} \mathrm{~L}$-ascorbic acid, distilled water and 30 $\mu \mathrm{L}$ of protein extract, in a total volume of $2 \mathrm{~mL}$, was incubated at $28^{\circ} \mathrm{C}$. The ascorbate oxidation rate was monitored at $290 \mathrm{~nm}$ for $3 \mathrm{~min}$ at 15 -s intervals and enzyme activity was expressed as $\mu \mathrm{mol}$ ascorbate oxidized per minute per $\mathrm{mg}$ of protein.

Guaiacol peroxidase assay (GPX; E.C. 1.11.1.7) - The activity of GPX was determined according to Souza and MacAdam (1998), observing the tetraguaiacol formation at $28^{\circ} \mathrm{C}$. The reaction mixture, with $2 \mathrm{~mL}$ of final volume, contained $50 \mathrm{mmol} \mathrm{L}^{-1}$ potassium phosphate buffer $(\mathrm{pH} 7.0)$, hydrogen peroxide $\left(\mathrm{H}_{2} \mathrm{O}_{2}\right), 3.5 \mathrm{mmol} \mathrm{L} \mathrm{L}^{-1}$ guaiacol, distilled water and $10 \mu \mathrm{L}$ of protein extract. The increase in absorbance due to guaiacol oxidation (extinction coefficient of 26.6 $\mathrm{mmol} \mathrm{L} \mathrm{cm}^{-1}$ ) was measured at $470 \mathrm{~nm}$ for $1 \mathrm{~min}$ at $10-\mathrm{s}$ intervals. The enzyme activity was expressed as $\mu \mathrm{mol}$ of guaiacol decomposed per minute per mg of protein.

Glutathione reductase assay (GR; E.C. 1.6.4.2) - GR activity was determined as described by Cakmak and Horst (1991), following the decrease in absorbance at $340 \mathrm{~nm}$ due to NADPH oxidation. The reaction mixture containing 50 mmol L ${ }^{-1}$ potassium phosphate buffer ( $\left.\mathrm{pH} 7.8\right), 1 \mathrm{mmol}$ $\mathrm{L}^{-1}$ oxidized glutathione (GSSG), $0.075 \mathrm{mmol} \mathrm{L}^{-1} \mathrm{NADPH}$, distilled water and $30 \mu \mathrm{L}$ of protein extract, was incubated at $28^{\circ} \mathrm{C}$. GR activity was calculated using an extinction coefficient of $6.2 \mathrm{mmol} \mathrm{L}^{-1} \mathrm{~cm}^{-1}$, measured at $340 \mathrm{~nm}$ for $3 \mathrm{~min}$ at 15 -s intervals. The activity of the enzyme was expressed as $\mu \mathrm{mol}$ of NADPH per minute per mg of protein.

The experiment was conducted using a randomized block statistical design consisting of three Cd levels $(0,45$ and $\left.90 \mu \mathrm{mol} \mathrm{L})^{-1}\right)$ and three sampling dates $(1,12$ and $20 \mathrm{~d})$. Data were submitted to analysis of variance using the $F$ test and results were presented as mean \pm standard error of mean (SEM) of three replicates, and to the Tukey test at $5 \%$.

\section{Results and Discussion}

Increasing Cd content in the nutrient solution increased the metal content in roots and shoots of $P$. glomerata plants (Figure 1A). In the root part the highest values were observed in the treatment at $90 \mu \mathrm{mol} \mathrm{Cd} \mathrm{L}{ }^{-1}\left(1223 \mathrm{mg} \mathrm{kg}^{-1}\right)$, while in the shoot part for the same treatment, Cd concentration was $238 \mathrm{mg} \mathrm{kg}^{-1}$. There were not significant differences in biomass production of the shoot between treatments, whereas the root biomass was higher in control treatment (Figure 1B). As a consequence of $\mathrm{Cd}$ accumulation in the tissues visual symptoms of toxicity were observed, including leaf wilting and yellowing as well as root darkening.

Overall, species that tolerate heavy metals should present them widely distributed in the roots which may result in morphological and metabolic changes, for instance reduced plant size and changes in antioxidant enzyme activity (Verbruggen et al., 2009). In this study, $P$. glomerata exhibited high concentrations of $\mathrm{Cd}$ in its tissues and yet it did not undergo major morphological changes, particularly in the treatment at $45 \mu \mathrm{mol} \mathrm{L}{ }^{-1}$, thus demonstrating some tolerance to the heavy metal. 

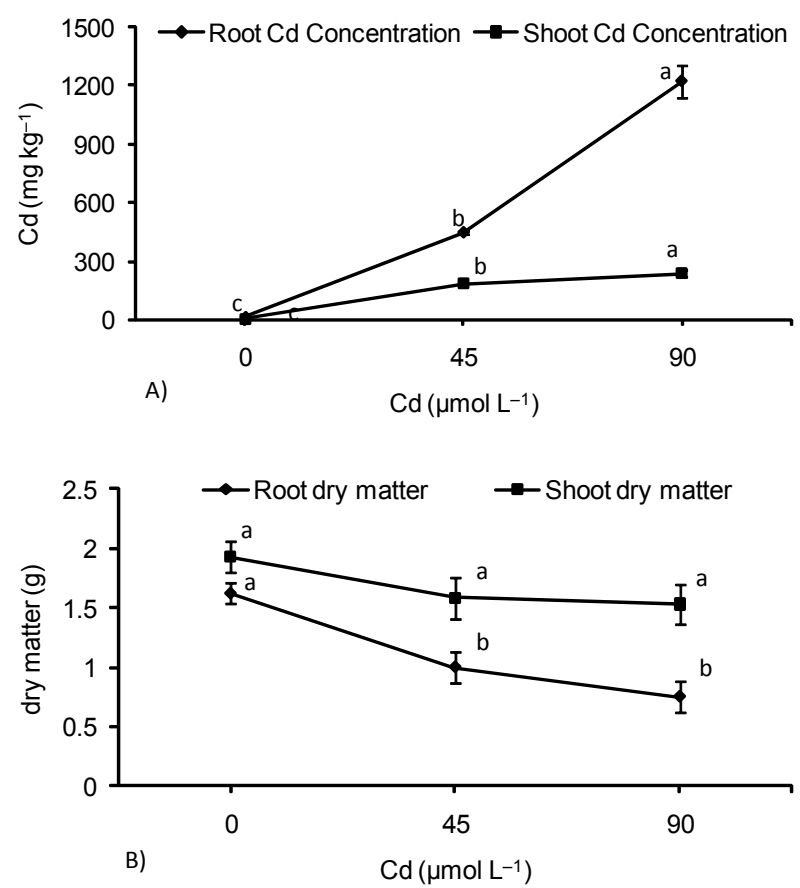

Figure 1 - Cd concentrations (A) and dry matter yield (B) in roots and shoots of $P$. glomerata subjected to concentrations of $\mathrm{Cd}$ for 20 days. Bars indicate the standard error of mean $(\mathrm{n}=3)$. Means followed by the same letter do not differ (Tukey, $p<0.05$ ).

The impact that a heavy metal exert on a plant will depend on how sensitive the species is and the metals bioavailability present in the soil during the plant growing (Smical et al., 2008). A tolerant specie may be defined as that which produces a amount of roots in contaminated areas (Punz and Sieghardt, 1993), as was observed with $P$. glomerata. Many tolerant plants are endemic in contaminated places because they have developed a variety of avoidance mechanisms by which the excess of heavy metal can be rendered harmless. The hability to develop heavy metal resistance is due chiefly to morphophysiological changes (Raskin et al., 1994).

Reactive oxygen species are considered to be the indicators of cell damage because lipid peroxidation in vivo provides a steady supply of free radicals. The effect of $\mathrm{Cd}$ on cell membrane integrity was determined through MDA measurement (Figures 2A and B). An increase was observed in lipid peroxidation in the leaves of $P$. glomerata with the increase in $\mathrm{Cd}$ content and increase in the exposure periods. The maximum effect was noted at $20 \mathrm{~d}$ after induction $(107 \%)$ on leaves, and $12 \mathrm{~d}$ after induction $(154 \%)$ on roots, both at $90 \mu \mathrm{mol} \mathrm{L}^{-1}$ concentration A reduction was observed in MDA contents in the roots with increasing exposure to the metal up to concentration of $45 \mu \mathrm{mol} \mathrm{Cd} \mathrm{L} \mathrm{L}^{-1}(58.7$ (1 d) to 32.6 (20 d) nmol MDA g ${ }^{-1} \mathrm{FW}$ ), while at $90 \mu \mathrm{mol} \mathrm{Cd} \mathrm{L}^{-1}$ concentration the MDA content increased on day 12 (45.5 (1 d) to 72.4 (12 d) nmol MDA g $\left.{ }^{-1} \mathrm{FW}\right)$.

Plant cell membranes are considered primary targets of metal-induced injuries and membrane destabilization is usu-
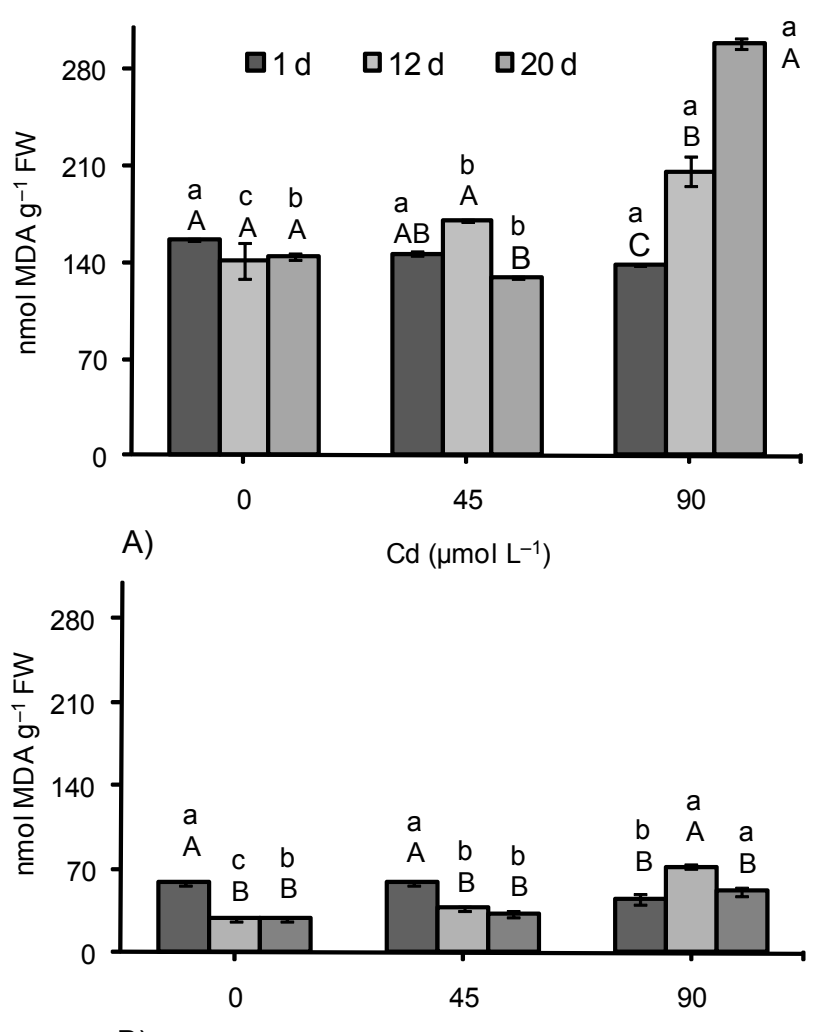

B) $\quad \mathrm{Cd}\left(\mu \mathrm{mol} \mathrm{L}{ }^{-1}\right)$

Figure 2 - Lipid peroxidation in leaves (A) and roots (B) of $P$. glomerata subjected to three concentrations of $\mathrm{Cd}$ in nutrient solution. Bars indicate means \pm standard error of three replicates. Means followed by the same letter do not differ (Tukey, $p<0.05$ ) (A-C denotes significance between sampling dates, within the same Cd level; a-c denotes significance between levels for the same sampling date).

ally attributed to lipid peroxidation (Singh, 2006). Increased MDA formation in plants exposed to $\mathrm{Cd}$ has been verified in sunflowers (Gallego et al., 1996), in peas (Dixit et al., 2001), in Thlaspi caerulescens and Brassica juncea accumulator species and also Nicotiana tabacum, a non-accumulator species (Wang et al., 2008).

The enzymes of the antioxidant system exhibited variations in activity when exposed to different $\mathrm{Cd}$ concentrations and different exposure periods. The activity of SOD, which is responsible for the dismutation of superoxide radicals from the cells, increased in the leaves at the beginning with a maximum activity increase of $41 \%$ (at $45 \mu \mathrm{mol} \mathrm{L}^{-1}$ after 1 d). Increasing $\mathrm{Cd}$ contents did not change SOD activity in leaves on day 20. (Figure 3A). An increase was verified in the activity of SOD in the roots at 20 days $\left(1.6 \mathrm{U} \mathrm{mg}^{-1}\right.$ protein $\left(0 \mu \mathrm{mol} \mathrm{L}{ }^{-1}\right)$ to $3.5 \mathrm{U} \mathrm{mg}^{-1}$ protein $\left(90 \mu \mathrm{mol} \mathrm{L}^{-1}\right)$ with increasing $\mathrm{Cd}$ contents in the nutrient solution. The maximum SOD activity increase observed in the roots was 203\% (at 45 $\mu \mathrm{mol} \mathrm{L} \mathrm{L}^{-1}$ after $20 \mathrm{~d}$ ). (Figure 3B).

Treatments with Cd are reported to have reduced SOD activity in non-accumulator bean plants (Somashekaraiah et al., 1992), sunflowers (Gallego et al., 1996) and peas (Sandalio 

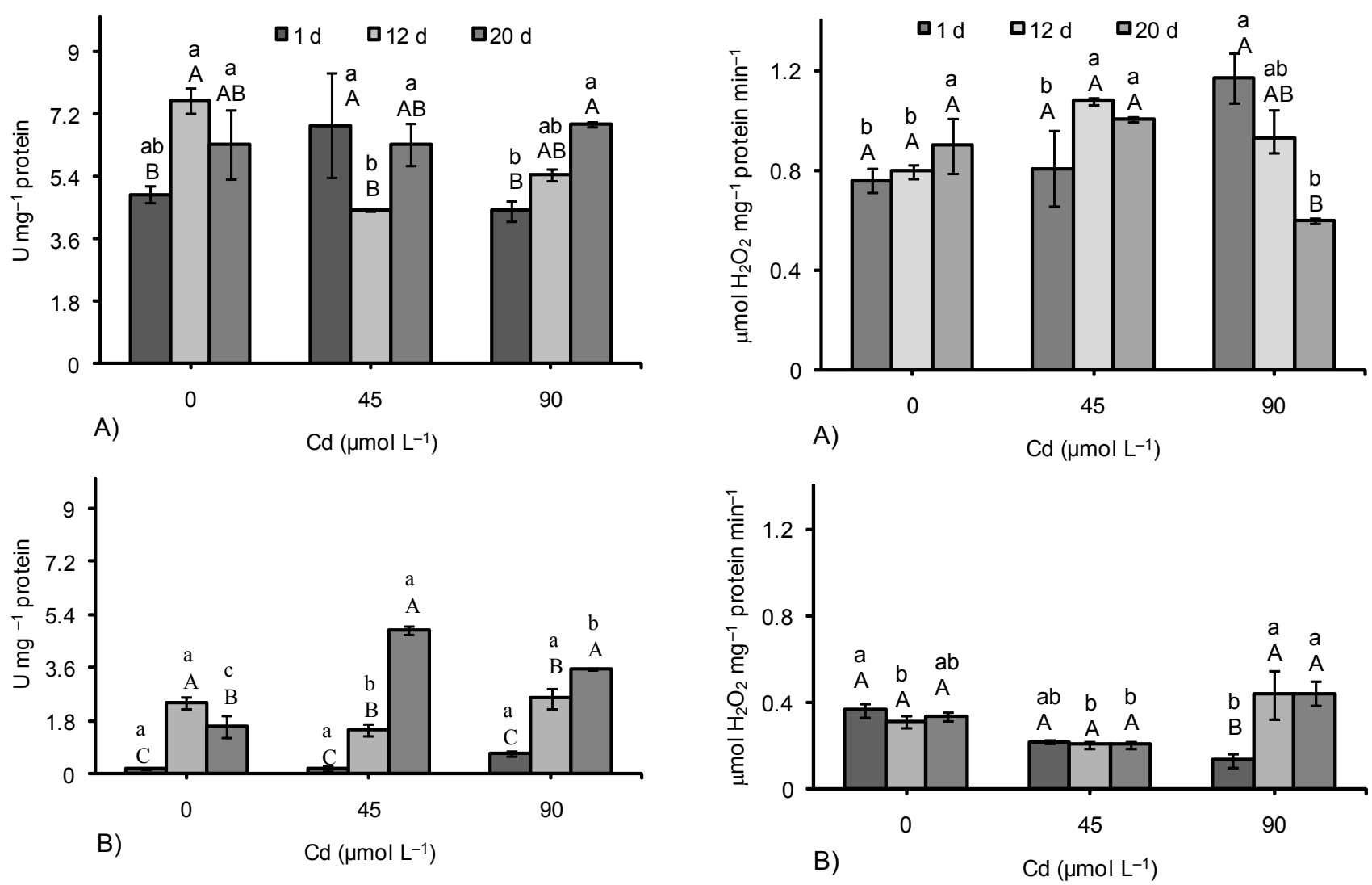

Figure 3 -SOD activity in leaves (A) and roots (B) of $P$. glomerata subjected to three concnetrations of $\mathrm{Cd}$ in nutrient solution. Bars indicate means \pm standard error of three replicates. Means followed by the same letter do not differ (Tukey, $p<0.05$ ) (A-C denotes significance between sampling dates, within the same Cd level; a-c denotes significance between levels for the same sampling date).

et al., 2001) and to have increased SOD activity in Alyssum lesbiacum, an accumulator species (Schickler and Caspi, 1999), and mustard (Mobin and Klan, 2007). In this study, high levels of SOD activity can protect $P$. glomerata against oxidative damage induced by Cd toxicity, when in combination with increased activity of other antioxidant enzymes, promoting the elimination of excess $\mathrm{H}_{2} \mathrm{O}_{2}$ which causes damage to the cells (Gossett et al., 1994).

The excessive increase in $\mathrm{H}_{2} \mathrm{O}_{2}$ was minimized through the activity of CAT, APX and GPX. In the leaves, the maximum increase in CAT activity was of $54 \%$ in relation to the control (at $90 \mu \mathrm{mol} \mathrm{Cd} \mathrm{L}{ }^{-1}$ after $1 \mathrm{~d}$ ). Yet, at this same concentration a maximum reduction was observed, down to $34 \%$, after $20 \mathrm{~d}$ (Figure $4 \mathrm{~A}$ ). In the roots, CAT activity showed a maximum increase of $42 \%$ (at $90 \mu \mathrm{mol} \mathrm{L}^{-1}$ after $12 \mathrm{~d})$ and it was similar to the control at $90 \mu \mathrm{mol} \mathrm{Cd} \mathrm{L^{-1 }}$ after $20 \mathrm{~d}$ (Figure 4B). Increased CAT activity is reported in Alyssum lesbiacum, a metal accumulator species (Schickler and Caspi, 1999), mustard (Mobin and Klan, 2007; Wang et al., 2008) and Thlaspi caerulesens (Wang et al., 2008). Considering that CAT is directly regulated by $\mathrm{H}_{2} \mathrm{O}_{2}$ levels (Polidoros and Scandalios, 1999), the increased activity in leaves with all levels of $\mathrm{Cd}$ at the initial stage suggests that

Figure 4 - CAT activity in leaves (A) and roots (B) of $P$. glomerata subjected to three concnetrations of $\mathrm{Cd}$ in nutrient solution. Bars indicate means \pm standard error of three replicates. Means followed by the same letter do not differ (Tukey, $p<0.05$ ) (A-C denotes significance between sampling dates, within the same Cd level; a-c denotes significance between levels for the same sampling date).

this enzyme was more active when first exposed to metal, while in the roots this increased CAT activity was observed at $90 \mu \mathrm{mol} \mathrm{L}^{-1}$ after $12\left(0.43 \mu \mathrm{mol} \mathrm{H}_{2} \mathrm{O}_{2} \mathrm{mg}^{-1}\right.$ protein $\left.\min ^{-1}\right)$ and $20 \mathrm{~d}\left(0.44 \mu \mathrm{mol} \mathrm{H}_{2} \mathrm{O}_{2} \mathrm{mg}^{-1}\right.$ protein $\left.\mathrm{min}^{-1}\right)$. The maintenance of high CAT activity in $\mathrm{Cd}$ accumulator species is an aspect that may be part of the tolerance mechanism of this plant species to the metal.

At the start and end of the experiment, the levels of APX activity in the leaves were statistically similar to the control. Yet, the highest increase in APX activity in the leaves was observed after $12 \mathrm{~d}$ with maximum increases of $64 \%$ and $43 \%$ (at 45 and at $90 \mu \mathrm{mol} \mathrm{L}^{-1}$, respectively) (Figure $5 \mathrm{~A}$ ). APX activity in leaves appeared to be less affected than CAT activity when the plant was exposed to higher $\mathrm{Cd}$ contents for longer periods, since CAT was reduced at $90 \mu \mathrm{mol} \mathrm{L} \mathrm{L}^{-1}$ after $20 \mathrm{~d}$, while APX activity remained similar to the control. In roots, the highest level of $\mathrm{Cd}\left(90 \mu \mathrm{mol} \mathrm{L}^{-1}\right)$ after 20 $\mathrm{d}$ increased APX activity $\left(4.9 \mu \mathrm{mol}\right.$ ascorbate $\mathrm{mg}^{-1}$ protein (12 d) to $9.4 \mu \mathrm{mol}$ ascorbate $\mathrm{mg}^{-1}$ protein $(20 \mathrm{~d})$ ), though after $12 \mathrm{~d}$ APX activity decreased in Cd presence (14 at control to $4.4 \mu \mathrm{mol}$ ascorbate $\mathrm{mg}^{-1}$ protein $\mathrm{min}^{-1}$ at $90 \mu \mathrm{mol} \mathrm{L}^{-1}$ ) (Figure $5 \mathrm{~B}$ ). In the latter situation, the inadequate response of APX activity in the elimination of $\mathrm{H}_{2} \mathrm{O}_{2}$ was offset by the 

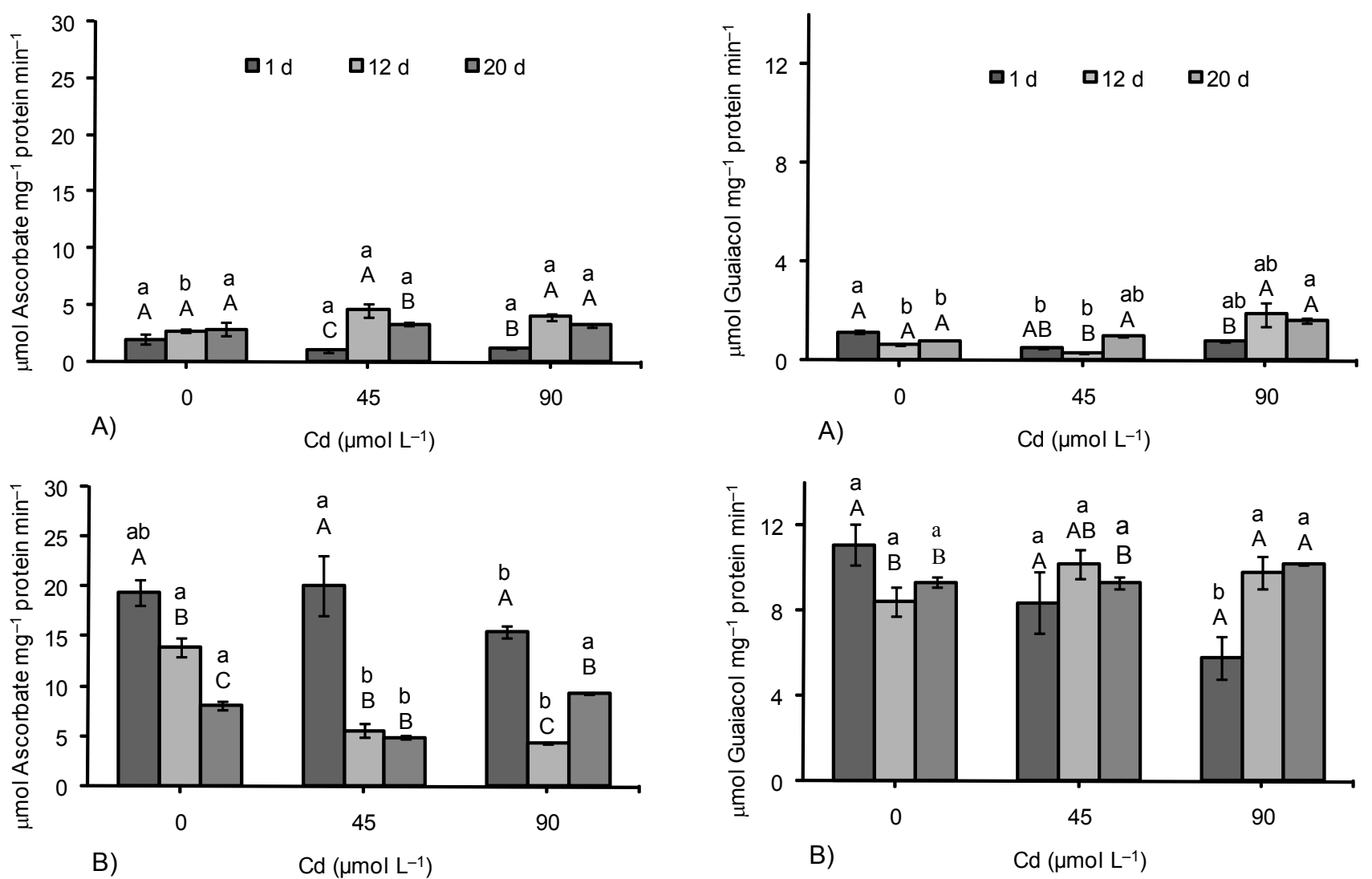

Figure 5 - APX activity in leaves (A) and roots (B) of $P$. glomerata subjected to three concentrations of $\mathrm{Cd}$ in nutrient solution. Bars indicate means \pm standard error of three replicates. Means followed by the same letter do not differ (Tukey, $p<0.05$ ) (A-C denotes significance between sampling dates, within the same Cd level; a-c denotes significance between levels for the same sampling date).

increase in CAT activity. Although higher amounts of $\mathrm{Cd}$ accumulated in root tissue, higher relative APX activities were observed in leaves of $P$. glomerata, when compared to the control, i.e. roots only presented a slight percentage increase in the enzyme activity. According to Vitória et al. (2001), evidence points to the existence of a sign of oxidative stress being transported from roots to leaves, and this signaling mechanism was reported by Karpinski et al. (1999), increasing APX transcription in leaves. Similar results to those in roots and leaves of $P$. glomerata, regarding APX activity, were found for Bacopa monnieri (Singh et al., 2006).

Guaiacol peroxidase activity increased in the leaves to a maximum of $183 \%$ and $95 \%$ (at $90 \mu \mathrm{mol} \mathrm{L}^{-1}$ after 12 and $20 \mathrm{~d}$, respectively) (Figure 6A). After 12 and 20 days, there was an increase in the GPX activity following an increase in the metal concentration. In the roots, GPX activity changed only slightly in relation to the control to maximum rates of $21 \%$ and $17 \%$ (at 45 and at $90 \mu \mathrm{mol} \mathrm{L}^{-1}$, after $12 \mathrm{~d}$, respectively). At the start of the experiment, after $1 \mathrm{~d}$ the stress induced by Cd reduced GPX activity by $48 \%$ in the treatment at $90 \mu \mathrm{mol} \mathrm{L}{ }^{-1}$ (Figures 6B).

In this study there was an increase in GPX activity in leaves following exposure to $\mathrm{Cd}(0.8$ at control to $1.6 \mu \mathrm{mol}$

Figure 6 - GPX activity in leaves (A) and roots (B) of P. glomerata subjected to three concentrations of $\mathrm{Cd}$ in nutrient solution. Bars indicate means \pm standard error of three replicates. Means followed by the same letter do not differ (Tukey, $p<0.05$ ) (A-C denotes significance between sampling dates, within the same Cd level; a-c denotes significance between levels for the same sampling date).

guaiacol $\mathrm{mg}^{-1}$ protein $\min ^{-1}$ at $90 \mu \mathrm{mol} \mathrm{L}^{-1}$ ), suggesting that this enzyme acts as an intrinsic protection against oxidative damage in P. glomerata. In Bacopa monnieri, GPX activity in leaves is reported to have been stimulated by increase both in exposure time and in concentrations of $\mathrm{Cd}$ (Singh et al., 2006). However, these authors observed a reduction in the activity of the enzyme in roots with the increased exposure to $\mathrm{Cd}$ at the highest concentration $\left(200 \mu \mathrm{mol} . \mathrm{L}^{-1}\right)$. An increase in GPX activity was also observed in Lycopersicon esculentum when exposed to $\mathrm{Cd}$, due to wide availability of $\mathrm{H}_{2} \mathrm{O}_{2}$ produced by stress, particularly toward the end of the experiment (Ammar et al., 2008).

Glutathione redutase showed a increase in activity in the leaves after 12 and $20 \mathrm{~d}$ at both concentrations of $\mathrm{Cd}(45$ and $90 \mu \mathrm{mol} \mathrm{L} \mathrm{L}^{-1}$ ) (Figure 7A). Both in leaves and in roots the highest increase in GR activity occurred after $12 \mathrm{~d}$, with $63 \%$ in the leaves (at $45 \mu \mathrm{mol} \mathrm{L}^{-1}$ ) and $78 \%$ in the roots (at $\left.90 \mu \mathrm{mol} \mathrm{L}{ }^{-1}\right)$. In the roots, the activity of the enzyme was reduced to levels below the control at all $\mathrm{Cd}$ concentrations tested after $1 \mathrm{~d}\left(1.4\right.$ at control to $0.8 \mu \mathrm{mol} \mathrm{NADPH} \mathrm{m}{ }^{-1}$ protein $\mathrm{min}^{-1}$ at $\left.90 \mu \mathrm{mol} \mathrm{L}^{-1}\right)$ and $20 \mathrm{~d}(1.2$ at control to 0.5 $\mu \mathrm{mol} \mathrm{NADPH} \mathrm{mg} \mathrm{m}^{-1}$ protein $\mathrm{min}^{-1}$ at $\left.90 \mu \mathrm{mol} \mathrm{L}^{-1}\right)$ of exposure (Figure 7B). 

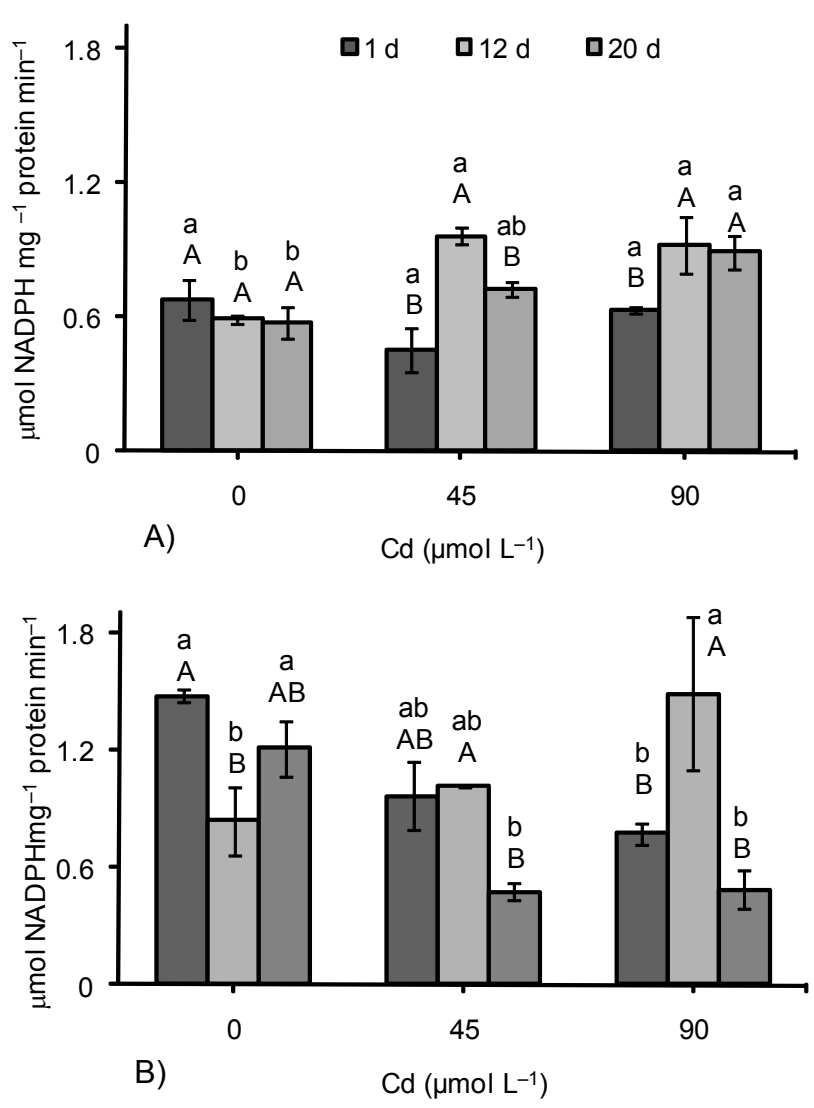

Figure 7 - GR activity in leaves (A) and roots (B) of P. glomerata subjected to three concentrations of $\mathrm{Cd}$ in nutrient solution. Bars indicate means \pm standard error of three replicates. Means followed by the same letter do not differ (Tukey, $p<0.05$ ) (A-C denotes significance between sampling dates, within the same Cd level; ac denotes significance between levels for the same sampling date).

Glutathione reductase, which catalyses the NADPH-dependent reduction of oxidized GSSG to the reduced form GSH, is involved in defence against oxidative stress. Glutathione is one of the major redox buffers in most aerobic cells and plays an important role in physiological functions, including redox regulation, conjugation of metabolites, detoxification of xenobiotics and homeostasis and cellular signaling that trigger adaptive responses (Noctor et al., 2002). Moreover, accumulation of GSSG is often associated with death or quiescence (Foyer and Noctor, 2003). Small variations were observed in GR activity with increasing exposure time to Cd in pea leaves (Sandalio et al., 2001). As observed in this study, GR activity was higher in roots than in leaves of radish plants subjected to Cd (Vitória et al., 2001). In Alyssum argenteum hyperaccumulator species, low contents of Cd induced GR activity while higher contents reduced the activity (Schickler and Caspi, 1999). According to the authors, this reduction could be the result of direct binding of $\mathrm{Cd}$ to the sulfhydryl group of the enzyme, influencing the glutathione cycle. GR activity is important to maintain a high GSH/GSSG ratio, being critical to the functioning of the glu- tathione-ascorbate cycle and phytochelatin synthesis (Cobbett, 2000), which in turn are responsible for the tolerance of the species to contamination by heavy metals, especially $\mathrm{Cd}$ (Benavides et al., 2005).

The low CAT activity in leaves on $20 \mathrm{~d}$ may have favored a larger participation of the ascorbate-glutatione cycle as a tolerance mechanism. That is possible because there was an increase in the GR enzyme activity, whereas APX activity remained the same as the control. The ability to do so presumably reflects enhanced engagement of other pathways of $\mathrm{H}_{2} \mathrm{O}_{2}$ detoxification (Noctor et al., 2002), notably the ascorbate-glutathione cycle, as evidenced by the sustained oxidation of glutathione accompanied by increases in the total glutathione pool.

In this study, $P$. glomerata presented concentrations above $100 \mathrm{mg} \mathrm{Cd} \mathrm{kg}^{-1}$ (Baker, 1981), meaning it is capable of tolerating high concentrations of $\mathrm{Cd}$ in its tissues. According to Baker (1981), it could be classified as a hyperaccumulator species, yet further studies are needed before characterizing it as a phytoremediator. Other results suggested that Cd-induced increase in the activity levels of antioxidant enzymes can constitute a secondary defense mechanism against oxidative stress, though not as direct a mechanism as phytochelatin production and compartmentalization in the vacuole. Here, the differentiated responses of antioxidant enzymes to $\mathrm{Cd}$ in roots and leaves can be attributed to variation in ROS formation levels due to differing functionality of the two plant organs, with the root being a nonphotosynthetic tissue and thus resulting in reduced electron flow. As for the higher accumulation of $\mathrm{Cd}$ in the roots, the level of free $\mathrm{Cd}$ may be low given the fact that the bulk of the metal ions may be immobilized or compartmentalized in the vacuole or else forming a complex with phytochelatins. As for the leaves, the lower accumulation of Cd due to transport barriers, along with the activities of antioxidant enzymes, reduced oxidative damage, increasing the tolerance of the species to Cd.

$P$. glomerata showed some superior antioxidative defense to adapt to the oxidative stress induced by Cd toxicity. MDA content was similar to the control at the mean level of $\mathrm{Cd}$. Accordingly, the activities of antioxidative enzymes increased or remained the same as the control until this concentration of the metal. Then, the coordinated increase of activities of antioxidative enzymes was effective in some protecting the plant from accumulation of ROS under Cd stress.

\section{Acknowledgements}

To Dr. Daniela Deitos Freis for the support on enzyme analyses and to the Fundação de Amparo à Pesquisa do Estado de Minas Gerais (FAPEMIG) for providing financial support.

\section{References}

Alscher, R.G.; Erturk, N.; Heath, L.S. 2002. Role of superoxide dismutases (SODs) in controlling oxidative stress in plants. Journal of Experimental Botany 53: 1331-1341.

Ammar, W.B.; Nouairi, I.; Zarrouk, M.; Ghorbel, M.H.; Jemal, F. 2008. Antioxidative response to cadmium in roots and leaves of tomato plants. Biologia Plantarum 52: 727-731. 
Azevedo, R.A..; Alas, R.M.; Smith, R.J.; Lea, P.J. 1998. Response of antioxidant enzymes to transfer from elevated carbon dioxide to air and ozone fumigation, in the leaves and roots of wild-type and a catalase-deficient mutant of barley. Physiologia Plantarum 104: 280-292.

Baker, A.J.M. 1981. Accumulators and excluders: strategis in the response of plants to heavy metals. Journal of Plant Nutrition 3: 643-654.

Beauchamp, C.; Fridovich, I. 1971. Superoxide dismutase improved assays and assay applicable to acrylamide gels. Analytical Biochemistry 44: 276-287.

Benavides, M.P.; Gallego, S.M.; Tomaro, M.L. 2005. Cadmium toxicity in plants. Brazilian Journal of Plant Physiology 17: 21-34.

Bradford, J.M. 1976. A rapid and sensitive method for qualification of microgram quantities of protein utilizing the principle of proteindye binding. Analytical Biochemistry 72: 248-254.

Buege, J.A.; Aust, S.D. 1978. Microsomal lipid peroxidation. Methods Enzymology 52: 302-310.

Cakmak, I.; Horst, W.J. 1991. Effect of aluminium on lipid peroxidation, superoxide dismutase, catalase and peroxidase activities in root tips of soybean (Glycine max). Physiologia Plantarum 83: 463-468.

Carneiro, M.A.C.; Siqueira, J.O.; Moreira, F.M.S. 2002. Behavior of herbaceous species in soil mixes with different degree of contamination with heavy metal. Pesquisa Agropecuária Brasileira 37:1629-1638.

Clark, R.B. 1975. Characterization of phosphatase of intact maize roots. Journal of Agricultural Food Chemistry 23: 458-460.

Cobbett, C.S. 2000. Phytochelatins and their roles in heavy metal detoxification. Plant Physiology 123: 825-832.

Dixit, V.; Pandey, V.; Shyam, R. 2001. Differential antioxidative responses to cadmium in roots and leaves of pea (Pisum sativum L. cv. Azad). Journal of Experimental Botany 52: 1101-1109.

Foyer, C.H.; Noctor, G. 2003. Redox sensing and signaling associated with reactive oxygen in chloroplasts, peroxisomes and mitochondria. Plysiologia Plantarum 119: 355-364.

Foyer, C.H.; Noctor, G. 2005. Redox homeostasis and antioxidant signaling: a metabolic interface between stress perception and physiological responses. Plant Cell 17: 1866-1875.

Gallego, S.M.; Benavides, M.P.; Tomaro, M.L. 1996. Effect of heavy metal ion excess on sunflower leaves: evidence for involvement of oxidative stress. Plant Science 121: 151-159.

Gossett, D.R.; Millhollon, E.P.; Lucas, M.C.; Bank, S.W.; Marney, M.M. 1994. The effects of $\mathrm{NaCl}$ on antioxidant enzyme activities in callus tissue of salt-tolerant and salt-sensitive cotton cultivars (Gossypium hirsutum L.). Plant Cell Report 13: 498-503.

Heath, R.L.; Packer, L. 1968. Photoperoxidation in isolated chloroplasts. I. Kinetics and stoichiometry of fatty acid peroxidation. Archives of Biochemistry and Biophysics 125: 189-198.

Karpinski, S.; Reynolds, H.; Karpinska, B.; Wingsle, G.; Creissen, G.; Mullineaux, P. 1999. Systemic signaling and acclimation in response to excess excitation energy in Arabidopsis. Science 284: 654-657.

Kraus, T.E.; Mckersie, B.D.; Fletcher, R.A. 1995. Paclobutrazol-induced tolerance of wheat leaves to paraquat may involve increased antioxidant enzyme activity. Journal of Plant Physiology 145: 570-576.

Mobin, M.; Khan, N.A. 2007. Photosynthetic activity, pigment composition and antioxidative response of two mustard (Brassica juncea) cultivars differing in photosynthetic capacity subjected to cadmium stress. Journal of Plant Physiology 164: 601-610.

Montanari, I.J.R.; Magalhães, P.M.; Queiroga, C.L. 1999. Influence of plantation density and cultivation cycle on root productivity and tonors of b-ecdsyone in Pfaffia glomerata (Spreng) Pedersen. Acta Horticulture 3: 125-128.

Nakano, Y.; Asada, K. 1981. Hydrogen peroxide is scavenged by ascorbato-specific peroxidase in spinach chloroplasts. Plant Cell Physiology 22: 867-880.
Noctor, G; Gomez, L.; Vanacker, H.; Foyer, C.H. 2002. Interactions between biosynthesis, compartimentation and transport in the control of glutathione homeostasis and signalling. Journal of Experimental Botany 53: 1283-1304.

Polidoros, A.N.; Scandalios, J.G. 1999. Role of hydrogen peroxide and different classes of antioxidants in the regulation of catalase and glutathione S-transferase gene expression in maize (Zea mays L.). Physiologia Plantarum 106: 112-120.

Punz, I.; Sieghardt, H. 1993. The response of roots of herbaceous plant species to heavy metal. Environmental and Experimental Botany 44: 85-98.

Raskin, I.; Kumar, P.B.A.N.; Dushenkov, S.; Salt, D.E. 1994. Bioconcentration of heavy metals by plants. Current Opinion in Biotechnology 5: 285-290.

Sandalio, L.M.; Dalurzo, H.C.; Gómez, M.; Romero-Puertas, M.C.; Rio, L.A. 2001. Cadmium-induced changes in the growth and oxidative metabolism of pea plants. Journal of Experimental Botany 52: 2115-2126.

Schickler, H.; Caspi, H. 1999. Response of antioxidative enzymes to nickel and cadmium stress in hyperaccumulator plants of the genus Alyssum. Physiologia Plantarum 105: 39-44.

Silva, F.C. 1999. Manual of soil, plant, and fertilizer analyses. EMBRAPA, Brasília, DF, Brazil. (in Portuguese).

Singh S.; Eapen, S.; D’Souza, S.F. 2006. Cadmium accumulation and its influence on lipid peroxidation and antioxidative system in an aquatic plant, Bacopa monnieri L. Chemosphere 62: 233-246.

Smical, A.I.; Hotea, V.; Oros, V.; Juhaz, J.; Pop, E. 2008. Studies on transfer and bioaccumulation of heavy metals from soil into lettuce. Environmental Engineering and Management Journal 7:609-615.

Somashekaraiah, B.V.; Padmajana, K.; Prasad, A.R.K. 1992. Phytotoxicity of cadmium ion on germinating seedlings of mung bean (Phaseolus vulgaris): involvement of lipid peroxides in chlorophyll degradation. Physiologia Plantarum 85: 85-89.

Souza, I.R.P.; MacAdam, J.W. 1998. A transient increase in apoplastic peroxidase activity preceds decrease in enlogation rate of B73 maize (Zea mays L.) leaf blades. Physiologia Plantarum 104: 556562.

Srivastava, M.; Ma, L.Q.; Singh, N.; Singh S. 2005. Antioxidant responses of hyper-accumulator and sensitive fern species to arsenic. Journal of Experimental Botany 56: 1335-1342.

Vandenabeele, S.; Vanderauwera, S.; Vuylsteke, M.; Rombauts, S.; Langebartels, C.; Seidlitz, H.K.; Zabeau, M.; Van Montagau, M.; Inzé, D.; Van Breusegem, F. 2004. Catalase deficiency drastically affects gene expression induced by high light in Arabidopsis thaliana. The Plant Journal 39: 45-58.

Verbruggen, N.; Hermans, C.; Schat, H. 2009. Mechanisms to cope with arsenic or cadmium excess in plants. Current Opinion in Plant Biology 12: 364-372.

Vitória, A.P.; Lea, P.J.; Azevedo, R.A. 2001. Antioxidant enzymes responses to cadmium in radish tissues. Phytochemistry 57: 701710.

Wang, Z.; Zhang, Y.; Huang, Z.; Huang; L. 2008. Antioxidative response of metal-accumulator and non-accumulator plants under cadmium stress. Plant and Soil 310: 137-149.

Willekens, H.; Chamnongpol, S.; Davey, M.; Schraudner, M.; Langebartels, C.; VanMontagu, M.; Inzé, D.; Van Camp, W. 1997. Calatase is a sink for $\mathrm{H}_{2} \mathrm{O}_{2}$ and is indispensable for stress defence in C3 plants. EMBO Journal 16: 4806-4816.

Received March 10, 2010

Accepted October 07, 2010 